\title{
LEAF EPIDERMAL CHARACTERISTICS OF MEDICINAL Eclipta prostrata (L.) L., Vernonia amygdalina Delile (ASTERACEAE) AND Clitoria ternatea L. (FABACEAE)
}

\author{
NURSHAHIDAH MOHD RUSLI ${ }^{*}$, MOHD NORFAIZAL GHAZALLI ${ }^{1}$, NORAINI TALIP ${ }^{2}$, \\ SAMSIAH JUSOH ${ }^{3}$, RAZALI MIRAD ${ }^{1}$, ROSNANI ABD. GHANI ${ }^{4}$, \\ WAN KHAIRUL ANUAR WAN ALI', MOHD RANI AWANG ${ }^{3}$, \\ NOOR ISMAWATY NORDIN ${ }^{4}$ and AHMAD ARIF ISMAIL ${ }^{5}$ \\ ${ }^{1}$ Agrobiodiversity and Environment Research Centre, Malaysian Agricultural Research and \\ Development Institute (MARDI), Persiaran MARDI-UPM, 43400 Serdang, Selangor \\ ${ }^{2}$ Department of Biological Sciences and Biotechnology, Faculty of Science and Technology, \\ Universiti Kebangsaan Malaysia, 43600 Bangi, Selangor \\ ${ }^{3}$ Industrial Crop Research Centre, MARDI Jerangau, KM 50, Jalan Ajil-Jerangau, \\ Kampung Landas, 21820 Ajil, Terengganu \\ ${ }^{4}$ Industrial Crop Research Centre, Malaysian Agricultural Research and Development Institute (MARDI), \\ Persiaran MARDI-UPM, 43400 Serdang, Selangor \\ Industrial Crop Research Centre, MARDI Bachok, Kampung Aur, Mukim Telong, \\ Jalan Kandis, 16310 Bachok, Kelantan \\ *E-mail: nurshahidahmohdrusli@gmail.com
}

Accepted 24 April 2021, Published online 30 June 2021

\begin{abstract}
A study on leaf anatomical characteristics was undertaken on three medicinal plants species, Eclipta prostrata (L.) L., Vernonia amygdalina Delile and Clitoria ternatea L. It is found that there are variables in leaf epidermal features such as anticlinal wall patterns, stomata types, trichome types, and the occurrence of secretory structures. Results showed that there is slight variation in anticlinal wall patterns, which is, sinuous on abaxial surfaces and straight to wavy on adaxial surfaces of Eclipta prostrata, straight to wavy on both abaxial and adaxial surfaces of Vernonia amygdalina, and sinuous on both abaxial and adaxial surfaces of Clitoria ternatea, two types of stomata, which is anomocytic in Eclipta prostrata and Vernonia amygdalina, and paracytic in Clitoria ternatea, six types of trichomes recorded such as simple multicellular (short stalk - blunted tip), simple multicellular (echinate ornamentation, pointed tip), simple unicellular (echinate ornamentation, pointed tip), irregular T-shaped glandular (short to long stalk - elongated terminal), capitate glandular (short stalk - unicellular terminal) and peltate glandular. Secretory cells were observed in two species, Eclipta prostrata and Vernonia amygdalina. The leaf of these three medicinal species has been widely used in herbal preparation, however, there are not enough information nor a comprehensive study was done on the leaf anatomy of these species. Therefore, this study aimed to provide additional knowledge and more detailed information of the epidermal characteristics of Eclipta, Vernonia and Clitoria and contributes to systematic data available.
\end{abstract}

Key words: Anatomy, Asteraceae, Clitoria ternatea, Eclipta prostrata, Fabaceae, leaf epidermal, medicinal plants, Vernonia amygdalina

\section{INTRODUCTION}

Family Asteraceae, formerly known as Compositae, is the second largest family of flowering plants (Cronquist 2001), represented by about 950 genera

\footnotetext{
* To whom correspondence should be addressed.
}

and 23000 species (Gills 1988), widely distributed throughout the world except for Antarctica (Funk \& Susanna 2009). The members of the family are mostly herbs, sometimes shrubs and a few are trees (Bremer 1994). While family Fabaceae is known as one of the largest family amongst Angiosperms. This plant is 
native to many African countries (Mukherjee et al., 2008) but has been extensively cultivated in the humid lowland tropics of Asia, Africa, Pacific Islands and Americas, and widespread throughout SouthEast Asia (Staples 1992).

Two of the species, Eclipta prostrata and Vernonia amygdalina belong to the family Asteraceae. Eclipta prostrata, locally known as Urang-aring, is an annual or short-lived perennial herb, found all around the tropics, extending towards the warm temperate, mostly found at the cultivated areas, along with watercourses and roadsides, about $10-80 \mathrm{~cm}$ tall, with prostrate erect branches, and numerous small, white heads (Burkill 1966; Jukema et al., 1991). On the other hand, Vernonia amygdalina, locally known as bismillah (Malay) or bitter leaf (English), due to its bitter taste, is a perennial shrub, grows wild in tropical Africa, small tree, about 1-6 m tall. The species is commonly grown and cultivated for its bitter leaves which are used for vegetables and medicinal purposes. Clitoria ternatea, locally known as kacang telang (Malay) or Butterfly Pea (English), is a member of the family Fabaceae. The plant is a perennial herbaceous climber and known for its deep-blue solitary flowers, used in food colouring and also medicinal purposes.

According to Rudall (1992), leaf epidermal surfaces characteristics are persistent characters in taxa, therefore, it has been used as the subject for study more than any other leaf parts. Leaf macromorphology characters such as shape, type, margin, apex and venation alone are not enough to give a precise decision in taxonomic conclusions and it is necessary to study the micro characters of the leaves to help in diagnosis (Taia 2004). Moreover, there are not enough information nor a comprehensive study was done on the leaf anatomy of these three medicinal species. Therefore, this study was designed to investigate and provide more detailed information and understanding of the epidermal characteristics and contributes to systematic data of genera Eclipta, Vernonia and Clitoria.

\section{MATERIALS AND METHODS}

\section{Sources of plant specimens}

Fresh specimens of Eclipta prostrata, Vernonia amygdalina and Clitoria ternatea with three replicates each, were collected from plots in the Malaysian Agricultural Research and Development Institute (MARDI) Serdang, Selangor. The specimens collected were authenticated by the curator/plant taxonomist at MARDI and the voucher specimens were deposited at the MDI Herbarium of the same institute.

\section{Epidermal peels}

Epidermal peels of both abaxial and adaxial surfaces of the three species were prepared by following a modified method of Johansen (1940) and Saas (1958). Pieces of $1 \mathrm{~cm}^{2}$ of the leaves of each specimen were cut and soaked in Jeffery's fluid (10\% nitric acid and $10 \%$ chromic acid, 1:1) in well-covered Petri dishes, for about four to six hours (depends on the sample) to macerate the mesophyll. The epidermis will be transferred into clean Petri dishes contain distilled water, then the abaxial and adaxial layers will be separated using a fine brush and forceps. The isolated epidermal layers then will be rinsed and cleansed with distilled water. Afterwards, the tissues were stained with Safranin and Alcian Blue solution for about five minutes each and then rinsed with distilled water to remove excess staining and transferred to a clear glass microscopic slide. The slides were then observed under a Fisher light microscope with $\times 20$ and $\times 40$ magnifications. Photographs of the epidermal peels were taken using Olympus SZH40 microscope (Tokyo, Japan) and images were processed using two software, Image Analysis and Adobe Photoshop. After observations, permanent slides were prepared. The tissues were then undergone dehydration process, using $50 \%$, $70 \%, 95 \%$ and $100 \%$ alcohol, and mounted on the slides using Euparal, covered with coverslips and placed in the oven at $60^{\circ} \mathrm{C}$ for nearly two weeks, before being kept in box slides for future references. Three slides were prepared for each abaxial and adaxial epidermal peels of the three species. Table 1 showed steps for staining, dehydration, mounting and drying of epidermal peels.

\section{Analysis and descriptions}

Details of the analysis and descriptions on epidermal anatomy characteristics followed those of Metcalfe and Chalk (1965).

\section{RESULTS AND DISCUSSION}

The epidermal cells and stomatal characteristics of the three species studied are summarized in Table 2 and illustrated in Figure 1, 2 and 3.

\section{Anticlinal walls}

The anticlinal wall in Eclipta prostrata is sinuous on abaxial surface, and straight to wavy on the adaxial surface (Figure 1), straight to wavy on both abaxial and adaxial surfaces of Vernonia amygdalina (Figure 2), and sinuous on both abaxial and adaxial surfaces of Clitoria ternatea (Figure 3). These results supported previous study on these species, that undulate-cuneate or sinuous anticlinal 
Table 1. Steps for staining, dehydration, mounting and drying process

\begin{tabular}{|c|c|c|c|}
\hline Step & Solution & Time & Notes \\
\hline \multicolumn{4}{|c|}{ Staining } \\
\hline 1 & $\begin{array}{l}2-3 \text { drops of Safranin into petri dish contains the tissue and } \\
\text { distilled water }\end{array}$ & 5 mins. & - \\
\hline 2 & Rinsed with distilled water. Repeat three times & - & - \\
\hline 3 & $\begin{array}{l}2-3 \text { drops of Alcian Blue into the Petri dish contains the tissue } \\
\text { and distilled water }\end{array}$ & 5 mins. & - \\
\hline 4 & Rinsed with distilled water. Repeat three times & - & - \\
\hline \multicolumn{4}{|c|}{ Dehydration } \\
\hline 1 & Alcohol $50 \%$ & 5 mins. & Close petri dish \\
\hline 2 & Alcohol $70 \%$ ( + a drop of hydrochloric acid- $\mathrm{HCl})$ & 2 mins. & $\begin{array}{l}\text { Close and stir petri } \\
\text { dish slowly }\end{array}$ \\
\hline 3 & Alcohol 95\% & 5 mins. & Close petri dish \\
\hline 4 & Alcohol $100 \%$ & 5 mins. & Close petri dish \\
\hline \multicolumn{4}{|c|}{ Mounting } \\
\hline & Euparal & - & \\
\hline \multicolumn{4}{|c|}{ Drying } \\
\hline & - & 2 weeks & $\begin{array}{l}\text { Placed in the oven } \\
\text { at } 60^{\circ} \mathrm{C}\end{array}$ \\
\hline
\end{tabular}

Table 2. Epidermal cells and stomatal characteristics of species studied

\begin{tabular}{|c|c|c|c|c|c|}
\hline Species & $\begin{array}{l}\text { Epidermal } \\
\text { surface }\end{array}$ & $\begin{array}{l}\text { Anticlinal } \\
\text { walls }\end{array}$ & $\begin{array}{l}\text { Stomatal } \\
\text { type }\end{array}$ & Trichome type & $\begin{array}{l}\text { Secretory } \\
\text { cells } \\
\text { occurrence }\end{array}$ \\
\hline \multirow[t]{2}{*}{$\begin{array}{l}\text { Eclipta } \\
\text { prostrata }\end{array}$} & Abaxial & Sinuous & Anomocytic & $\begin{array}{l}\text { Capitate glandular (short stalk - unicellular } \\
\text { terminal), } \\
\text { Simple multicellular (echinate ornamentation, } \\
\text { pointed tip) }\end{array}$ & Present \\
\hline & Adaxial & $\begin{array}{l}\text { Straight } \\
\text { to wavy }\end{array}$ & Anomocytic & $\begin{array}{l}\text { Simple multicellular (echinate ornamentation, } \\
\text { pointed tip), } \\
\text { Simple multicellular (short stalk - blunted tip) }\end{array}$ & Absent \\
\hline \multirow[t]{2}{*}{$\begin{array}{l}\text { Vernonia } \\
\text { amygdalina }\end{array}$} & Abaxial & $\begin{array}{l}\text { Straight } \\
\text { to wavy }\end{array}$ & Anomocytic & $\begin{array}{l}\text { Irregular T-shaped glandular (short to long } \\
\text { stalk - elongated terminal), } \\
\text { Peltate glandular }\end{array}$ & Absent \\
\hline & Adaxial & $\begin{array}{l}\text { Straight } \\
\text { to wavy }\end{array}$ & Anomocytic & $\begin{array}{l}\text { Simple multicellular (short to long stalk - } \\
\text { blunted tip), } \\
\text { Peltate glandular }\end{array}$ & Present \\
\hline \multirow[t]{2}{*}{$\begin{array}{l}\text { Clitoria } \\
\text { ternatea }\end{array}$} & Abaxial & Sinuous & Paracytic & $\begin{array}{l}\text { Simple multicellular (echinate ornamentation, } \\
\text { pointed tip), }\end{array}$ & Absent \\
\hline & Adaxial & Sinuous & Paracytic & $\begin{array}{l}\text { Simple multicellular (echinate ornamentation, } \\
\text { pointed tip) }\end{array}$ & Absent \\
\hline
\end{tabular}

walls occurred in Clitoria ternatea (Khatijah et al., 2006; Chukwuma et al., 2014) and straight-arcuate or undulating anticlinal walls occurred in Vernonia amygdalina (Adedeji \& Jewoola, 2008; Kemka et al., 2014). The anticlinal wall of Eclipta prostrata is reported for the first time.

\section{Stomata types}

The distribution of the stomata in all three species is amphistomatic, which is stomata occurring on both abaxial and adaxial surface (Table 2).
Anomocytic stomata were found to occur in Eclipta prostrata and Vernonia amygdalina (Figure 1B, 1F, $2 \mathrm{~B}$ and $2 \mathrm{~F}$ ), while paracytic stomata occurred in Clitoria ternatea (Figure $3 \mathrm{~A}$ and $3 \mathrm{D}$ ). This result supports Metcalfe and Chalk (1965), which reported that stomata in Compositae (Asteraceae) is generally 'ranunculaceous or anomocytic, and 'rubiaceous' or paracytic in Leguminosae (Fabaceae). Perveen et al. (2007) in a study on stomatal types of dicots, also reported that anomocytic stomata occurred in Eclipta prostrata. Chukwuma et al. (2014) reported 


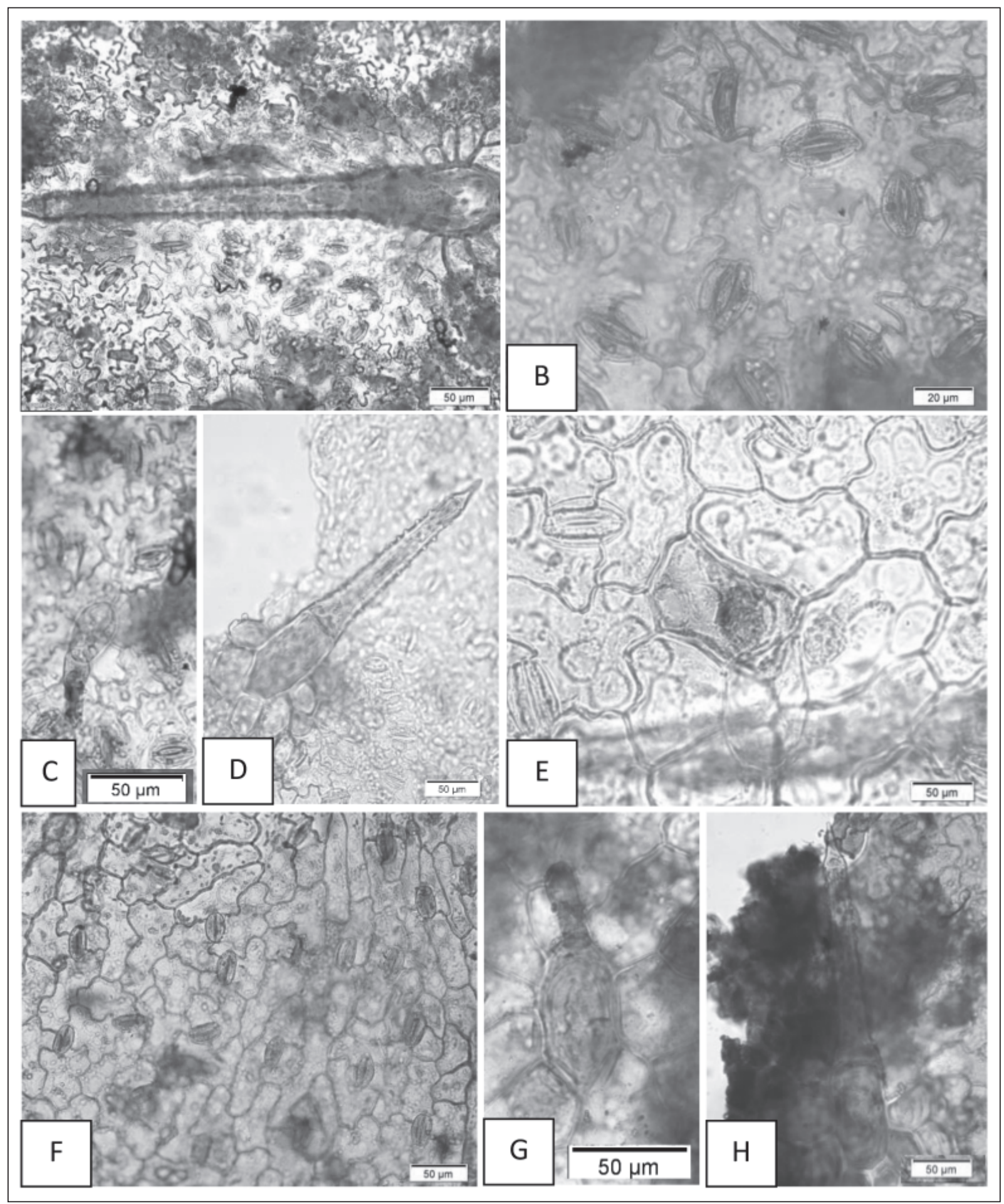

Fig. 1. Leaf epidermal of Eclipta prostrata. (A-E) Abaxial leaf surface. A) Sinuous anticlinal walls, B) Anomocytic stomata, C) Capitate glandular (short stalk - unicelular terminal), D) Simple multicellular (echinate ornamentation, pointed tip), E) Secretory cells. (F-H) Adaxial leaf surface. F) Straight to wavy anticlinal walls with anomocytic stomata, G) Simple multicellular (short stalk - blunted tip), H) Simple multicellular (echinate ornamentation, pointed tip). Scale: A, C-H) 50 $\mu \mathrm{m}$, B) $20 \mu \mathrm{m}$.

that there are three types of trichome present in Clitoria ternatea, which is paracytic, anisocytic and anomocytic, however, this study only found paracytic stomata.

\section{Trichome types}

There are five trichome types observed in the study, including both non-glandular and glandular types (Table 2). Non-glandular trichomes are 


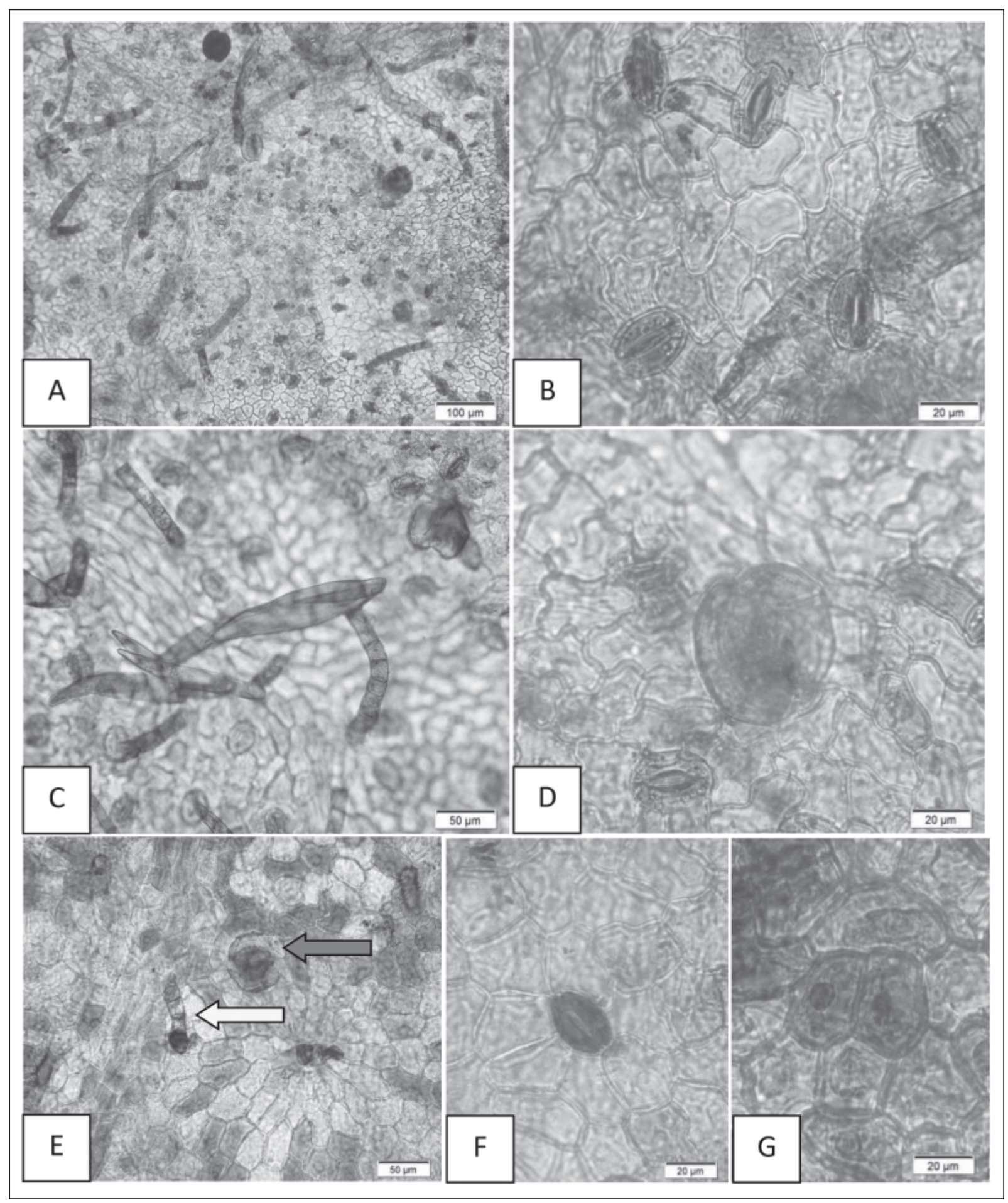

Fig. 2. Leaf epidermal of Vernonia amygdalina. (A-D) Abaxial leaf surface. A) Straight to wavy anticlinal walls, B) Anomocytic stomata, C) Irregular T-shaped glandular (short to long stalk - elongated terminal), D) Peltate glandular. (E-G) Adaxial leaf surface. E) Straight to wavy anticlinal walls with simple multicellular (short stalk - blunted tip), (yellow arrow) and peltate glandular (red arrow) trichomes, F) Anomocytic stomata, G) Secretory cells. Scale: A) $100 \mu \mathrm{m}, \mathrm{C} \& \mathrm{E})$ $50 \mu \mathrm{m}, \mathrm{B}, \mathrm{D}, \mathrm{F} \& \mathrm{G}) 20 \mu \mathrm{m}$.

simple multicellular (short stalk - blunted tip), simple multicellular (echinate ornamentation, pointed tip), and simple unicellular (echinate ornamentation, pointed tip), while glandular trichomes found are irregular T-shaped glandular (short to long stalk - elongated terminal), capitate glandular (short stalk unicellular terminal) and peltate glandular.

Three types of trichomes were found in Eclipta prostrata, capitate glandular (short stalk - unicellular terminal) (Figure 1C), simple multicellular (echinate 


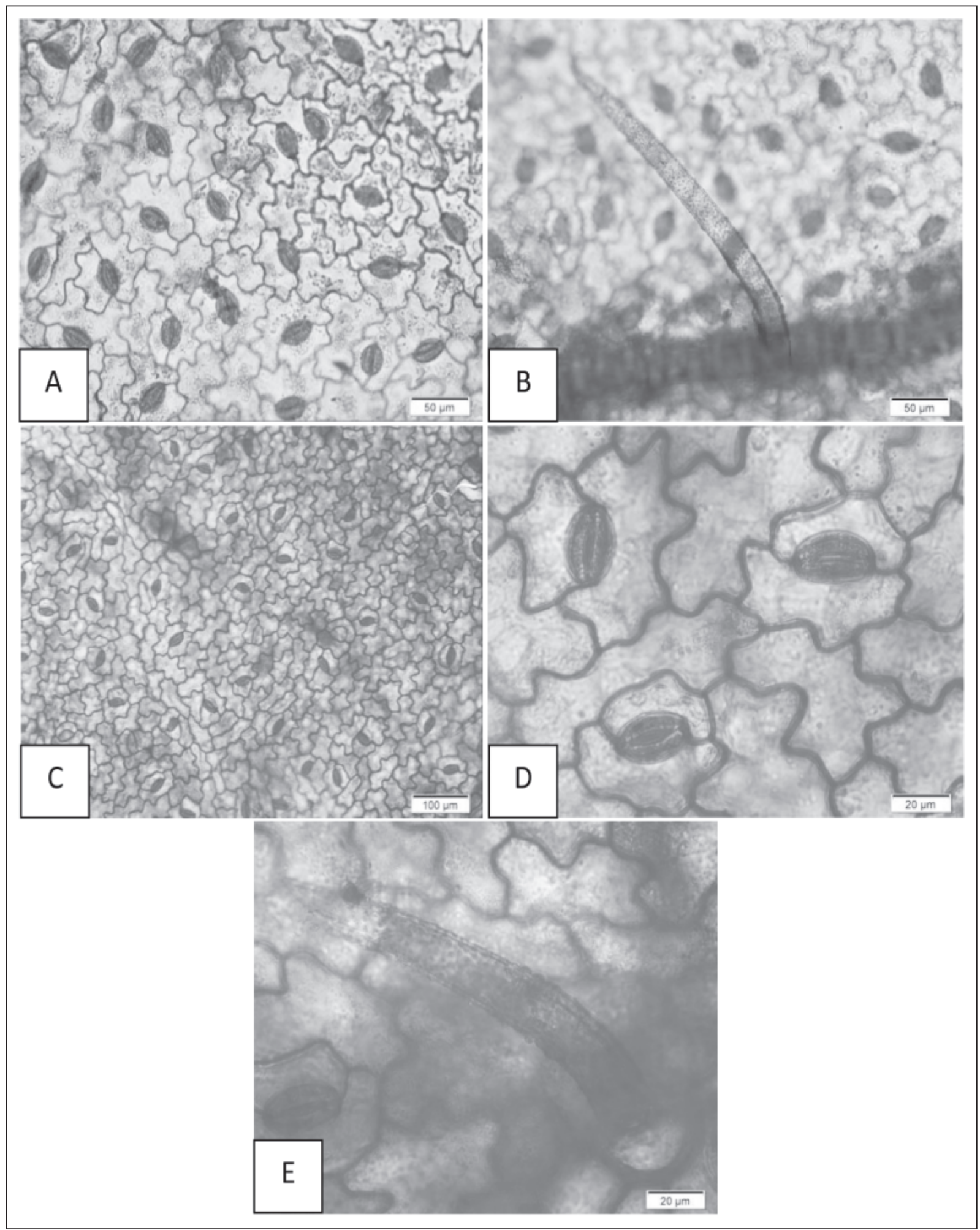

Fig. 3. Leaf epidermal of Clitoria ternatea. (A-B) Abaxial leaf surface. A) Sinuous anticlinal walls with paracytic stomata, B) Simple unicellular (echinate ornamentation, pointed tip), (C-E) Adaxial leaf surface. C) Sinuous anticlinal walls, D) Paracytic stomata, E) Simple unicellular (echinate ornamentation, pointed tip). Scale: A \& B) $50 \mu \mathrm{m}, \mathrm{C}) 100 \mu \mathrm{m}, \mathrm{D} \& \mathrm{E})$ $20 \mu \mathrm{m}$.

ornamentation, pointed tip) (Figure 1D), and simple multicellular (short stalk - blunted tip) (Figure 1G). Shafira and Salamah (2020) also reported the occurrence of simple multicellular (echinate ornamentation, pointed tip) and simple multicellular (short stalk - blunted tip) on leaves of Eclipta prostrata in their study on trichomes of four species in the family Asteraceae. This is the first time capitate 
glandular (short stalk - unicellular terminal) trichome reported for the species.

Three types of trichomes were also recorded in Vernonia amygdalina, which are, irregular T-shaped glandular (short to long stalk - elongated terminal) (Figure 2C), peltate glandular (Figure 2D), and simple multicellular (short stalk - blunted tip) (Figure 2E). This information supports the previous study done by Oladele (1990) and Kemka et al. (2014). They stated that the occurrence and morphology of the irregular T-shaped glandular and bilobed glandular trichome (peltate glandular) is a diagnostic character for Vernonia amygdalina. A simple multicellular (short stalk - blunted tip) trichome was also reported for the first time for Vernonia amygdalina.

Only one type of trichome was found Clitoria ternatea, which is simple unicellular (echinate ornamentation, pointed tip) (Figure 3B and 3E). Khatoon et al. (2015) also found the same trichomes in their pharmacognostical studies on blue and white flower varieties of Clitoria ternatea.

\section{Occurrence of secretory structures}

Castro et al. (1997) have mentioned that there are eight types of leaf secretory structures found in Asteraceae; ducts, cavities, idioblasts, laticifers, hydathodes, extrafloral nectaries, trichomes and glandular appendixes. According to Metcalfe and Chalk (1965), latex sometimes presents in elongated secretory cells in Vernonia, while the occurrence of secretory elements in Fabaceae can be in two ways, in cells or sacs.

Secretory structures were found in two species are, Eclipta prostrata and Vernonia amygdalina, both in ducts form and glandular trichomes. Clitoria ternatea, however, showed no occurrence of secretory structures. In Eclipta prostrata, the secretory cells are elongated, almost rectangular shape, while in Vernonia amygdalina, the cells are shorter and rounded. Lersten and Curtis (1987) also have discussed the wide variability in internal secretory structures of the Asteraceae. Despite their differences in positions and size, these secretory structures are usually filled with thick yellowish to a dark brown oil, in a form of spherical droplets.

\section{CONCLUSIONS}

This present finding has proved that leaf epidermal characteristics of Eclipta prostrata, Vernonia amygdalina and Clitoria ternatea, such as anticlinal wall patterns, stomata types, trichome types, and occurrence of secretory structures could serve useful in the identifications of these three medicinal plant species. While this work supports the previous study, there are also new findings reported, contributed to the existing taxonomic and systematic information on the species studied and may be used in the identification of the plant species in the absence of its inflorescences. The anticlinal wall of Eclipta prostrata is reported for the first time in this study. Capitate glandular (short stalk - unicellular terminal) trichome and simple multicellular (short stalk - blunted tip) trichome were also reported for the first time for Eclipta prostrata and Vernonia amygdalina respectively. Although leaf epidermal characteristics have contributed greatly to the taxonomy of angiosperms, more studies need to be done to provide detailed information and expand the knowledge on the species studied.

\section{ACKNOWLEDGEMENTS}

The authors are grateful to the Herbal Development Office (HDO) and Malaysian Herbal Monograph (MHM) for providing valuable support.

\section{REFERENCES}

Adedeji, O. \& Jewoola, O.A. 2008. Importance of epidermal characters in Asteraceae family. Notula Botanicae Horti Agrobotanici ClujNapoca, 36(2): 7-16.

Bremer, K. 1994. Asteraceae: Cladistics and Classification. Timber Press, Portland.

Burkill, L.H. 1966. A Dictionary of The Economic Products of Malay Peninsula. Vol. 1 (A-H). Ministry of Agriculture Malaysia, Kuala Lumpur.

Castro, M.M., Leitão-Filho, H.F. \& Monteiro, W.R. 1997. Utilização de estruturas secretoras na identificação dos gêneros de Asteraceae de uma vegetação de cerrado. Revista Brasileira de Botânica, 20: 163-174.

Chukwuma, E.C., Soladoye, M.O. \& Abdus Salaam, K.R.P. 2014. Taxonomic value of the leaf micromorphology and quantitative phytochemistry of Clitoria ternatea and Centrosema pubescens (Papilionoideae, Fabaceae). Phytologia Balcanica, 20(1): 3-8.

Cronquist, A. 2001. Vascular Flora of the Southeastern United States: Asteraceae. Vol. 1. The University of North Carolina Press, North Carolina

Funk, V.A. \& Susanna, A. 2009. Systematic Evolution and Biogeography of Compositae. International Association Plant Taxonomy, Vienna.

Gills, L.S. 1988. Taxonomy of Flowering Plants. Africana-Fep Publishers Limited, Nigeria.

Johansen, D.A. 1940. Plant Microtechnique. McGraw-Hill Book Co., New York. 
Jukema, J., Wulijarni-Soetjipto, N., Lemmens, R.H.M.J. \& Hildebrand, J.W. 1991. In: Eclipta alba (L.) Hassk. R.H.M.J Lemmens \& N. Wulijarni-Soetjipto (Eds.). Plant Resources of South-East Asia No. 3: Dye and tannin producing plants, Pudoc, Wageningen.

Kemka, C.I., Okoli, B. \& Nwachukwu, C.U. 2014. Epidermal studies of three species of Vernonia Schreb. in Southern Nigeria. Biodiversitas, 15(2): 137-141.

Khatijah, H., Mohamad-Ruzi, A.R. \& Nurulnahar, E. 2006. Malaysian Medicinal Plants. Vol. 4. Penerbit Universiti Kebangsaan Malaysia (UKM), Bangi.

Khatoon, S., Irshad, S., Rawat, A.K.S. \& Misra, P.K. 2015. Comparative pharmoacognostical studies of blue and white flower varieties of Clitoria ternatea L. Journal of Pharmacognosy and Natural Products, 1: 1.

Lersten, N.R. \& Curtis, J.D. 1985. Distribution and anatomy of hydathodes in Asteraceae. Botanical Gazette, 146: 106-114.

Metcalfe, C.R. \& Chalk, L. 1965. Anatomy of The Dicotyledons. Vol. 1. Oxford University Press, London.

Mukherjee, P.K., Kumar, V., Kumar, N.S. \& Heinrich, M. 2008. The ayurvedic medicine Clitoria ternatea: From traditional use to scientific assessment. Journal of Ethnopharmacology, 120(3): 291-201.
Oladele, F.A. 1990. Leaf epidermal features in Vernonia amygdalina and Vernonia cinerea. Nigerian Journal of Botany, 3: 71-77.

Perveen, A., Abid, R. \& Fatima, R. 2007. Stomatal types of some dicots within flora of Karachi, Pakistan. Pakistan Journal of Botany, 39(4): 1017-1023.

Rudall, P. 1992. Anatomy of Flowering Plants: An Introduction to Structure and Development. Vol. 2. Cambridge University Press, Cambridge.

Saas, J.E. 1958. Botanical Microtechnique. Vol. 3. Oxford \& IBH Publishing Co, Calcutta.

Shafira, S. \& Salamah, A. 2020. Analysis of leaves trichomes of Eclipta prostrata, Eleutheranthera ruderalis, Synedrella nodiflora and Tridax procumbens (Asteraceae, Heliantheae). IOP Conference Series: Earth and Environmental Science, 524: 012001.

Staples, I.B. 1992. Clitoria ternatea L. In: Plant Resources of South-East Asia No. 4: Forages. L.'t. Mannetje and R.M. Jones (Eds.). Pudoc, Netherlands.

Taia, W.K. 2004. Leaf characters within Tribe Trifolieae (Family Leguminosae). Pakistan Journal of Biological Sciences, 7(8): 1463-1472. 